\title{
Use of RANDom Amplfied Polymorphic DNA (RAPD) FOR GENERATING SPECIFIC DNA PROBES FOR OXYUROID SPECIES (NemATODA)
}

\author{
JOBET E.****, BOUGNOUX M.-E.*, MORAND S.**, RIVAULT C.***, \\ CLOAREC A.*** \& HUGOT J.-P.****
}

\begin{abstract}
Summary :
Random amplified DNA markers (RAPD; Williams et al., 1990) were used to obtained specific RAPD fragments characterising different species of oxyuroids. We tested six species of worms parasitizing vertebrates or invertebrates: Passalurus ambiguus Rudolphi, 1819, parasite of Leporids; Syphacia obvelata (Rudolphi, 1802) Seurat, 1916, a parasite of rodents; Blatticola blattae (Graeffe, 1860) Chitwood, 1932 parasite of the cockroach Blattella germanica; Hammerschmidtiella diesingi (Hammerschmidt, 1838) Chitwood, 1932 and Thelastoma bulhoesi (Magalhaes, 1990) Travassos, 1929, parasites of the cockroach Periplaneta americana, and an undescribed parasite species of a passalid insect from New Caledonia. Among 15 oligonucleotides tested, nine produced several specific bands allowing the interspecific discrimination.
\end{abstract}

KEY WORDS : RAPD-PCR, Oxyuroidea, Nematoda, taxonomic identification

\section{INTRODUCTION}

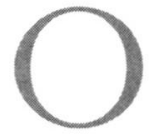
xyurid nematodes are monoxenous parasites of vertebrates and invertebrates (Adamson, 1989; Morand et al., 1996). Their taxonomy and phylogenetic relationships still remain confused, particularly for invertebrate parasites (Adamson, 1989; Adamson \& Van Waerebeke, 1992), and we suspect numerous cases of synonymy. These parasites have a haplo-diploid mode of reproduction and show a female-biased sex-ratio (Adamson, 1989). Males are often very small and rare. Moreover, in the case of congeneric species infecting the same host species, such as Dermoptera oxyuroids (Hugot, 1986), tortoises oxyuroids (Petter, 1966) or some invertebrate oxyuroids

\footnotetext{
* Laboratoire de Parasitologie-Mycologie, Hôpital Ambroise-Paré, 9, avenue Charles-de-Gaulle, F-92104 Boulogne-Cedex.

** Laboratoire de Biologie Animale (UMR 5555 du CNRS), Centre de Biologie et d'Écologie Tropicale et Méditerranéenne, Université de Perpignan, F-66860 Perpignan Cedex.

*** Laboratoire d'Ethologie (UMR 6552 du CNRS) Université de Rennes 1. Campus de Beaulieu, F-35042 Rennes Cedex.

**** Laboratoire de Biologie parasitaire (URA 114b CNRS), F-75231 Paris Cedex 05.

Correspondence : Edouard Jobet.

Email: Digene@univ-perp.fr - Fax : 0468662281.
}

Résumé : UtILISATION DES RAPD (RANDOM AMPLIFIED POLYMORPHIC DNA) POUR GÉNÉRER DES MARQUEURS SPÉCIFIQUES D'ESPECES D'OXYURES (NEMATODA)

La technique du RAPD (Random Amplified Polymorphic DNA, William et al., 1990) a été utilisée pour caractériser différentes espèces d'oxyures. Nous avons testé six espèces d'oxyures de vertébrés ou d'invertébrés: Passalurus ambiguus Rudolphi, 1819 un parasite de léporidés; Syphacia obvelata (Rudolphi, 1802) Seurat, 1916, un parasite de rongeurs; Blatticola blattae (Graeffe, 1860) Chitwood, 1932, parasite de la blatte Blattella germanica (L.); Hammerschmidtiella diesingi (Hammerschmidt, 1838) Chitwood, 1932, et Thelastoma bulhoesi Magalhaes, 1990) Travassos, 1929, parasites de la blatte Periplaneta americana, et une espèce non décrite d'un passalide de NouvelleCalédonie. Sur les 15 amorces testées, neut ont produit plusieurs bandes spécifiques permettant la différenciation interspécifique.

MOTS CLÉS : RAPD-PCR, Oxyuroidea, Nematoda, identification taxonomique

(Adamson \& Noble, 1992), it is difficult to assign a female to its species. More difficulties arise when taxonomic identification is based on individuals of one sex only. The use of molecular technics could hence be helpful to resolve such taxonomic problems (Bandi et al., 1993; Chacon et al., 1994; Andrews et al., 1995; Humbert \& Cabaret, 1995). Our aim was to test the use of RAPD markers method for resolving taxonomix problems by applying this method to six oxyuroid species: two species from vertebrate hosts and four from invertebrates.

\section{MATERIAL AND METHODS}

\section{PARASITE RECOVERY}

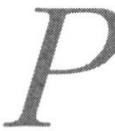

assalurus ambiguus (11 females and 10 males) was obtained from Oryctolagus cuniculus (Laboratory MNHN), Syphacia obvelata (50 females and one male) from Mus domesticus (Laboratory $\mathrm{MNHN}$ ), Hammerschmidtiella diesingi (25 females and nine males) and Thelastoma bulboesi ( 43 females and two males) from the cockroach Periplaneta americana (originated from one population in Paris), Blatticola blattae (93 females and 13 males) from the cockroach Blattella germanica (originated 
from two populations in Rennes and one population in Paris) and an undescribed species (five females) from a New-Caledonian Passalid.

Parasites were collected from the caecum of each host species, carefully washed in physiological saline and in tampon TE [10 mM TrisHCL pH 8, $1 \mathrm{mM}$ EDTA] before being stored and conserved at $-80^{\circ} \mathrm{C}$.

For each parasite sample, ceacum fluid were recovered and stored as mentioned above.

Males and females nematode were identified with confidence to their morphological characters, and according to Basir (1956) and Adamson \& van Waerebeke (1992).

\section{DNA EXTRACTION}

We used a modified protocol from Barral et al. (1996). DNA from caecum sample fluid was extracted following the same procedure.

\section{PCR AMPLIFICATIONS}

Fifteen oligonucleotides were used for the amplification of random DNA markers. Primer sequences were as follows:

RP2 5'-AAGGATCAGA-3'; VG1 5'-ACGTATCTGC-3'; MNH1 5'-ACGTCTATGC-3'; R108 5'-GTATTGCCCT-3'; RP4-2 5'-CACATGCTTC-3'; R28 5'-ATGGATCCGG-3';

\begin{tabular}{|c|c|c|c|c|c|c|c|c|c|}
\hline Primers & RP2 & MNH1 & $\mathrm{R} 28$ & OPAXS & OPB04 & OPGB & SB2 & OPB11 & OPA9 \\
\hline Concentration in $\mathrm{MgCl} 2$ & 2,5 & 3,5 & 3,5 & 1,5 & 3,5 & 2,5 & 1,5 & 2,5 & 2,5 \\
\hline \multicolumn{10}{|l|}{ Species } \\
\hline \multirow[t]{5}{*}{ P. ambiguus } & 1050 & 875 & 1050 & 1400 & 400 & 1250 & & & \\
\hline & 620 & 800 & & 500 & 320 & 700 & & & \\
\hline & & 600 & & & 150 & 450 & & & \\
\hline & & 575 & & & & & & & \\
\hline & & 390 & & & & & & & \\
\hline \multirow{8}{*}{ S. obvelata } & 1100 & 1050 & 1150 & 950 & 1550 & 850 & & 790 & 900 \\
\hline & & 900 & 1090 & 650 & 1400 & 800 & & 500 & 820 \\
\hline & & 550 & 1000 & 400 & 1320 & 550 & & 450 & 800 \\
\hline & & 450 & 850 & 350 & 1260 & 500 & & & 680 \\
\hline & & 440 & 800 & & 925 & & & & 600 \\
\hline & & & 750 & & 625 & & & & 560 \\
\hline & & & 700 & & 570 & & & & 520 \\
\hline & & & & & 350 & & & & \\
\hline \multirow[t]{7}{*}{ H. diesingi } & 1700 & 1200 & 1090 & 1250 & 1250 & 1700 & 1900 & & \\
\hline & 850 & 950 & 950 & 1100 & 600 & 1550 & 800 & & \\
\hline & 780 & 850 & 900 & 800 & 500 & 1120 & 675 & & \\
\hline & 680 & 675 & 750 & 575 & 270 & 1050 & 450 & & \\
\hline & 450 & 625 & 500 & 500 & & 600 & 440 & & \\
\hline & & 480 & 450 & 150 & & 575 & & & \\
\hline & & 300 & 375 & & & 525 & & & \\
\hline \multirow[t]{8}{*}{ T. bulhoesi } & 1750 & 1950 & 1250 & & 1600 & 825 & 1700 & & \\
\hline & 1600 & 1250 & 1050 & & 1300 & 750 & 1500 & & \\
\hline & 1350 & 875 & 800 & & 1200 & 700 & 1100 & & \\
\hline & 920 & 775 & 660 & & 900 & 480 & 1000 & & \\
\hline & 770 & 650 & 525 & & & 425 & 850 & & \\
\hline & 490 & 450 & 375 & & & 325 & 710 & & \\
\hline & 475 & 375 & 350 & & & & 450 & & \\
\hline & & & & & & & 300 & & \\
\hline \multirow[t]{5}{*}{ B. blattae } & 1100 & 1400 & 700 & & 1250 & 1450 & 1150 & 700 & 950 \\
\hline & 790 & 925 & 550 & & 700 & 700 & 910 & 590 & 650 \\
\hline & 580 & 725 & 360 & & 450 & 225 & 890 & 510 & 560 \\
\hline & & 450 & & & 350 & & 750 & 475 & 500 \\
\hline & & 275 & & & & & 290 & 400 & \\
\hline \multirow{6}{*}{$\begin{array}{l}\text { Undescribed species } \\
\text { of a passalid insect }\end{array}$} & 1300 & 1600 & 850 & 1000 & 1250 & 900 & & & \\
\hline & 600 & 1150 & 590 & 600 & 1150 & 775 & & & \\
\hline & 350 & 700 & 520 & & & 700 & & & \\
\hline & & & 250 & & & 575 & & & \\
\hline & & & & & & 500 & & & \\
\hline & & & & & & 475 & & & \\
\hline
\end{tabular}

Table I. - Specific bands generated by nine primers for each species of oxyuroids (optimal concentration in $\mathrm{MgCl} 2$, from 1.5 to $3.5 \mathrm{mM}$, was determined for each primer). 

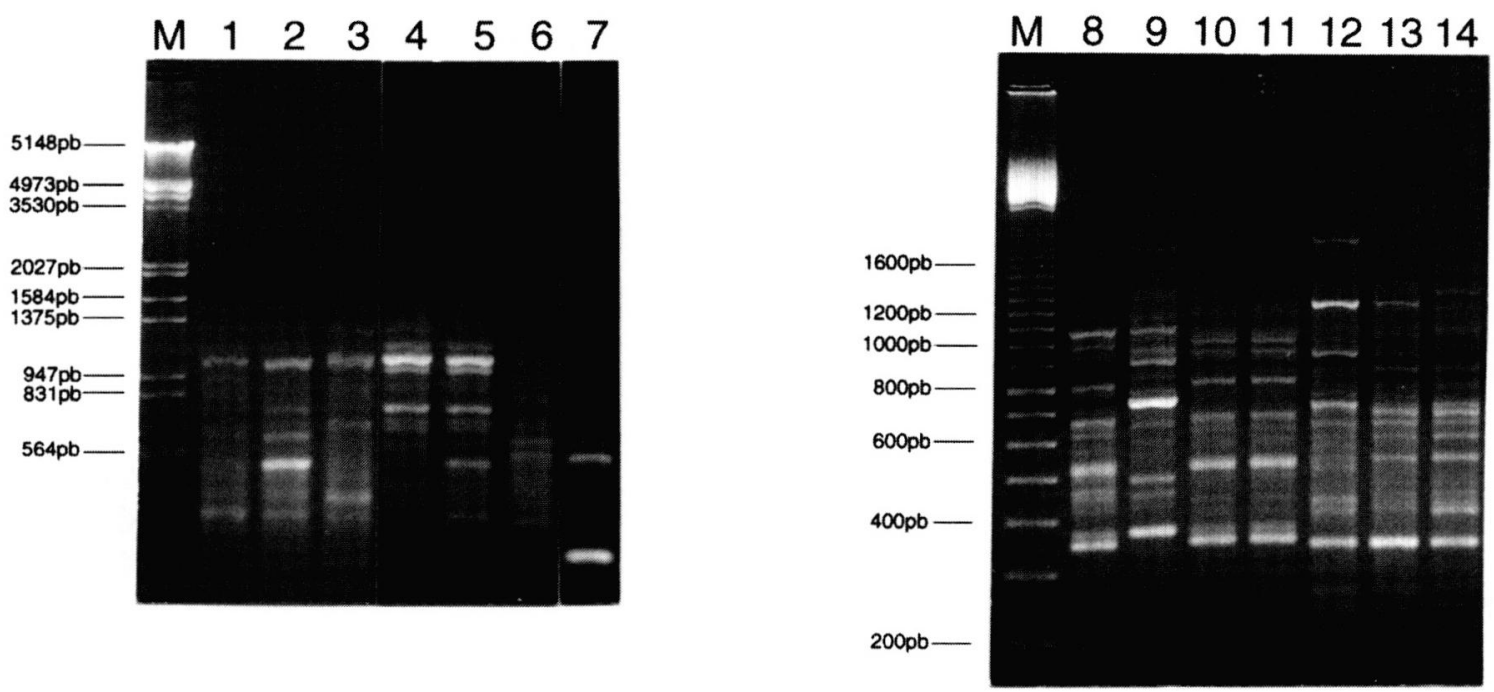

Figs 1-2. - Interspecific differences among 6 oxyurid species revealed with the R28 primer.

Fig. 1. - Column M: DNA-Eco RIplus Hin DIII marker with a $\lambda$ molecular weight; column 1: P. ambiguus (5 gravid females); column 2: $P$. ambiguus (10 males); column 3: DNA gut fluid of P. ambiguus host; column 4: S. obvelata (4 gravid females); column 5: S. obvelata (4 non-gravid females); column 6: DNA gut fluid of $S$. obvelata host; column 7: Passalidae oxyurids (5 gravid females).

\section{M 456}

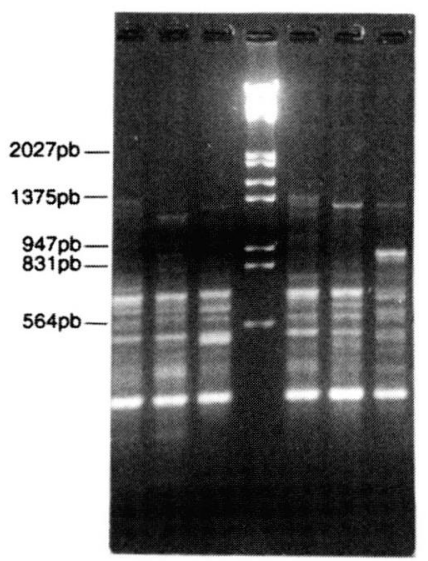

Fig. 3. - Intraspecific differences among 6 B. blattae ( 6 females) with R28 primer.

Column M: DNA-Eco RIplusHin DIII marker with a $\lambda$ molecular weight; columns 1 to 6 : 6 different females of $B$. blattae.

OPAXS 5'-AGTGCACACC-3'; OPB04 5'-GGACTGGAGT-3'; OPB11 5'-GTAGACCCGT-3'; SB1 5'AGGTCCCTGC-3'; SB2 5'-TGCACCCTGC-3'; OPGB 5'GAGCCCTCCA-3'; OPA9 5'-GGGTAACGCC-3'; A2 5'-TGGTCGCGGC-3'; NS33 5'-GCCAGCAGCC-3'.

The PCR reaction was carried out in a volume of $25 \mu \mathrm{l}$ containing $10 \mathrm{mM}$ Tris $\mathrm{HCl} \mathrm{pH} \mathrm{8.3,50} \mathrm{mm} \mathrm{KCl} 1 \mathrm{U}$ of Taq DNA polymerase (Boehringer Mannheim $\mathrm{GmbH}$, Germany), $200 \mu \mathrm{M}$ of each dNTP (dATP, dCTP, dGTP, dTTP), 50 pmole primer and a final concentration of $\mathrm{MgCl} 2$ depending of the primer used. From 25 to
Fig. 2. - Culumn M: marker with a 100PairBaseLadder molecular weight ; column 8: T. bulboesi (7 gravid females); column 9: H. diesing $i$ (10 gravid females); columns 10 and 11: T. bulhoesi (10 and 5 gravid females respectively); columns 12, 13 and 14: B. blattae (19, 21 and 2 gravid females respectively).

\section{$12345 \mathrm{M}$}

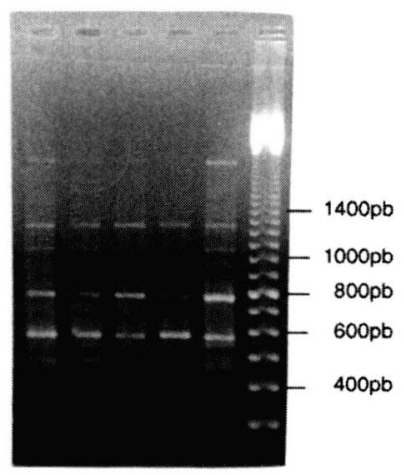

Fig. 4. - Intraspecific differences among 5 B. blattae ( 5 males) with RP2 primer.

Column M: marker with a 100PairBaseLadder molecular weight columns 1 to 5: 5 different males of $B$. blattae.

$50 \mathrm{ng}$ total nematode DNA was used as a template for the PCR.

The PCR cycle was carried for 30 seconds at $94{ }^{\circ} \mathrm{C}$, for 30 seconds at $36{ }^{\circ} \mathrm{C}$ and for 75 seconds at $72{ }^{\circ} \mathrm{C}$ for a total of 44 cycles followed by an extension polymerisation reaction of five minutes at $72{ }^{\circ} \mathrm{C}$. Amplification was performed in a Perkin Elmer (9600) thermo cycler.

The amplified DNA fragments resulting from PCR were analysed directly on $1.5 \%$ agarose gels by ethidium bromide staining $(0.5 \mu \mathrm{g} / \mathrm{ml})$. The gels were run in TBE 
1X (BioProbe) at a constant voltage $(120 \mathrm{v})$ and photographed. The molecular sizes of the fragments were determined using the 100 bp DNA Ladder (Pharmacia Biotech, USA) or the $\lambda$ DNA-EcoRIplusHindIII (Boerhinger, Mannheim) as references.

Amplifications were performed twice to asses reproducibility and blanks were done without DNA template. To detect potential contamination of nematode DNA we performed RAPD experiments DNA sample extracted from host digestive fluid.

\section{RESULTS}

T he choice of primers were assessed in regard to the number of generated bands, the quality of the profiles and their reproducibility. The optimal concentration in $\mathrm{MgCl} 2$ was determined for each primer (Table I).

DNA patterns of host gut fluid control differed completely from nematode DNA patterns except in the case of $P$. ambiguus for which a number of fragments were similar in both control and DNA template.

Interspecific differentiation was easily assessed. Nine of 15 oligonucleotides assayed revealed unambiguous profiles (Table I). Each of these primers generated patterns that were specific of each nematode species. An example is given for primer R28 (Figs 1, 2). Similar results were obtained either by using individual or pooled nematodes.

Intraspecific variability was low and concerned non specific bands as showed in Figures 3 and 4. Patterns obtained by RAPD method for $B$. blattae from different origins were similar.

\section{DISCUSSION}

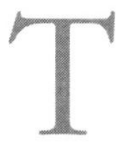

he RAPD method allows to distinguish the six studied species of oxyurids. For example, its possible to clearly distinguish the two oxyuroid species, $H$. diesingi and $T$. bulboesi, which occur in the same host, the cockroach $P$. americana.

Patterns obtained for males and females were identical. Therefore, this method is appropriate for resolving problems of taxonomic identification either in the case of synonymy or when only members of one sex (generaly females) were collected from their hosts (Adamson \& Noble, 1992).

We recorded a similarity in patterns generated by RAPD between $P$. ambiguus and its host environment (control). We hypothesize that these results arose because of the particular behaviour of the females of this species, which release their eggs into the internal environment. Hence, there is some chance that we may have also amplified also parasite egg DNA with host gut fluid.

Finally, the RAPD method revealed genetic variability among the six species of worms studied. This preliminary methodological study should enable further investigations of inter and intraspecific genetic variability.

\section{ACKNOWLEDGEMENTS}

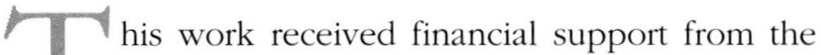
Ministère de l'Environnement (Comité EGPN) and the CNRS (Sciences de la Vie).

We thank an anonymous referee for its valuable comments.

\section{REFERENCES}

ADAMSON M.L. Evolutionary biology of the Oxyurida (Nematoda): biofacies of a haplodiploid taxon. Advances in Parasitology, 1989, 28, 175-228.

Adamson M.L. \& Noble S. Structure of the pinworm (Oxyurida: Nematoda) guild in the hindgut of the American cockroach, Periplaneta americana. Parasitology, 1992, 104, 497-507.

Adamson M.L. \& van Waerebeke. D. Revision of the Thelastomatoidae, Oxyurida of invertebrate hosts. Systematic Parasitology, 1992, 21, 21-63, 169-188; 22, 111-130.

Andrews J.R.H., Bandi C., Gomez Morales M.A., Ainsworth R. \& ABERNETHY D. Identification of Trichinella pseudospiralis from a human case using Random Amplified Polymorphic DNA. American Journal of Tropical Medecine and Hygiene, 1995, 53, 185-188.

Bandi C., larosa G., Comincini S., Damiani G. \& Pozio E. Random Amplified Polymorphic DNA Technique for the Identification of Trichinella Species. Parasitology, 1993 , 107, 419-424.

Barral V., Morand S., Pointier J.-P. \& Theron A. Distribution of schistosome genetic diversity within vertebrate definitive hosts by RAPD markers. Parasitology, 1996, 113, 511-517.

Chacon M.R., Rodrigez E., Parkhouse R.E.M., Burrows P.R. \& GARATE $T$. The differentiation of parasitic nematodes using Random Amplified Polymorphic DNA. Journal of Helminthology, 1994, 68, 109-113.

Morand S., Legendre P., Gardner S.L. \& Hugot J.-P. Body size evolution of oxyurid parasites: the role of hosts. Ecologia, 1996, 107, 274-282.

Petter A.J. Équilibre des espèces dans les populations de nématodes parasites du colon des tortues terrestres. Mémoires du Muséum National d'Histoire naturelle. Série A, Zoologie, 1966, 39, 252 p. 